\title{
BLAST FURNACE GAS AS A PRODUCT OF PIG IRON PRODUCTION
}

\author{
1Jaroslav MELECKÝ, ${ }^{2}$ Ladislav KOVÁŘ \\ ${ }^{1}$ VSB - Technical University of Ostrava, 17. listopadu 2172/15, Ostrava-Poruba, 70800, Czech Republic, EU, \\ jaroslav.melecky@vsb.cz \\ ${ }^{2}$ VSB - Technical University of Ostrava, 17. listopadu 2172/15, Ostrava-Poruba, 70800, Czech Republic, EU, \\ ladislav.kovar@vsb.cz
}

https://doi.org/10.37904/metal.2020.3461

\begin{abstract}
One of the products of pig iron production is blast furnace gas. Its pressure energy can be used, among other things, by including an expansion turbine with subsequent production of electricity. The contribution discusses the possibilities of calculating the thermodynamic quantities of blast furnace gas as a mixture of gases. The state equation of an ideal gas does not apply accurately enough over a wide range of temperatures and pressures. The inaccuracy of the ideal gas state equation generally increases with decreasing temperature and increasing pressure. To verify the dependence of gas thermodynamic quantities on pressure and to calculate state quantities under normal conditions, I present the so-called Benedict-Webb-Rubin equation, which can be easily derivable, so that from the pressure formula it is possible very easily to obtain formulas for other thermodynamic variables, is sufficiently precise and the values of constants are set for a large number of gases.
\end{abstract}

Keywords: Pig iron, blast furnace gas, state equation, thermodynamic quantities

\section{INTRODUCTION}

In the case of blast furnace gas as one of the products of pig iron production, it is necessary to know its composition, temperature and pressure in order to be able to objectively assess its other possible uses. It is known that thermodynamic quantities also depend on pressure. In this paper, this dependence is examined and the aim is to determine the conclusion whether it is necessary to seriously consider this dependence or not.

\section{COMPOSITION OF BLAST FURNACE GAS}

The concentrations of the blast furnace gas individual components take on the following values as standard, see Table 1.

Table 1 Standard composition of blast furnace gas

\begin{tabular}{|c|c|c|}
\hline Component & Volume part (1) & Weight part (1) \\
\hline $\mathrm{CO}$ & 0.225 & 0.209224807 \\
\hline $\mathrm{CO}_{2}$ & 0.18 & 0.262985863 \\
\hline $\mathrm{H}_{2}$ & 0.025 & 0.001673118 \\
\hline $\mathrm{N}_{2}\left(\mathrm{~N}_{2}+\mathrm{Ar}\right)$ & 0.56 & 0.520790282 \\
\hline $\mathrm{CH}_{4}$ & 0.01 & 0.005325930 \\
\hline
\end{tabular}


From the above table it is clear that the largest part in the blast furnace gas is occupied by nitrogen. In fact, it is a mixture of nitrogen and argon from the supplied air. A small part of the $\mathrm{CO}_{2}$ in the air is already contained in the measured proportion of $\mathrm{CO}_{2}$ in the blast furnace gas.

The following dry air composition is considered for the calculation, see Table 2.

Table 2 Standard composition of dry air

\begin{tabular}{|c|c|c|}
\hline Component & Volume part (1) & Weight part (1) \\
\hline $\mathrm{O}_{2}$ & 0.2095 & 0.231450008 \\
\hline $\mathrm{N}_{2}$ & 0.7809 & 0.755267378 \\
\hline $\mathrm{Ar}$ & 0.0093 & 0.012826775 \\
\hline $\mathrm{CO}_{2}$ & 0.0003 & 0.000455839 \\
\hline
\end{tabular}

The other components $\left(\mathrm{H}_{2}, \mathrm{O}_{3}\right.$ and inert gases $\left.\mathrm{Ne}, \mathrm{He}, \mathrm{Kr}, \mathrm{Xe}\right)$ do not need to be taken into account at all, as there are only slight traces of these gases in the air. Atmospheric nitrogen $\mathrm{N}_{2 \mathrm{~atm}}$, as a mixture of gases in air other than oxygen, is then assumed in the following standard composition, see Table 3.

Table 3 Standard composition of atmospheric nitrogen

\begin{tabular}{|c|c|c|}
\hline Component & Volume part (1) & Weight part (1) \\
\hline $\mathrm{N}_{2}$ & 0.987855787 & 0.982717306 \\
\hline $\mathrm{Ar}$ & 0.011764706 & 0.016689578 \\
\hline $\mathrm{CO}_{2}$ & 0.000379507 & 0.000593116 \\
\hline
\end{tabular}

As can be seen from Table 3, atmospheric nitrogen contains a certain amount of $\mathrm{CO}_{2}$. It is now clear that in the case of the calculation taking into account atmospheric nitrogen, it is necessary to recalculate the share of $\mathrm{CO}_{2}$ in the blast furnace gas to a new value, see Table 4. This will be smaller than the measured value of $\mathrm{CO}_{2}$ by the part that is already part of atmospheric nitrogen.

Table 4 Recalculated composition of blast furnace gas

\begin{tabular}{|c|c|c|}
\hline Component & Volume part (1) & Weight part (1) \\
\hline $\mathrm{CO}$ & 0.225 & 0.208679889 \\
\hline $\mathrm{CO}_{2}$ & 0.1797874 & 0.261991113 \\
\hline $\mathrm{H}_{2}$ & 0.025 & 0.001668761 \\
\hline $\mathrm{N}_{2 \mathrm{~atm}}$ & 0.5602126 & 0.52234817 \\
\hline $\mathrm{CH}_{4}$ & 0.01 & 0.005312058 \\
\hline
\end{tabular}

\section{REAL BEHAVIOR OF GASES}

The state equation of an ideal gas does not apply accurately enough over a wide range of temperatures and pressures, large deviations are especially noticeable in the critical point area. The inaccuracy of the equation of state of an ideal gas generally increases with decreasing temperature and increasing pressure.

There are a number of equations of state that describe with some degree of accuracy the real behavior of gases. In this paper, I used the so-called Benedict-Webb-Rubin equation (BWR equation) to verify the dependence of thermodynamic quantities of blast furnace gas on pressure and to calculate state quantities under normal conditions. 
The equations (1) to (7) can be written with a small modification according to [1,2], e.g. in the form:

$p=\frac{R T}{v_{m}}+\frac{B_{0} R T-A_{0}-\frac{C_{0}}{T^{2}}}{v_{m}^{2}}+\frac{b R T-a}{v_{m}^{3}}+\frac{\alpha a}{v_{m}^{6}}+\frac{c}{T^{2} v_{m}^{3}} \cdot\left(1+\frac{\gamma}{v_{m}^{2}}\right) \cdot e^{\frac{-\gamma}{v_{m}^{2}}}$

$u_{m}=u_{m}^{0}-\frac{A_{0}+\frac{3 C_{0}}{T^{2}}}{v_{m}}-\frac{a}{2 v_{m}^{2}}+\frac{\alpha a}{5 v_{m}^{5}}+\frac{3 c}{T^{2} v_{m}^{2}} \cdot\left(\frac{1-e^{\frac{-\gamma}{v_{m}^{2}}}}{\gamma} \cdot v_{m}^{2}-\frac{1}{2} \cdot e^{\frac{-\gamma}{v_{m}^{2}}}\right)$

$i_{m}=i_{m}^{0}+\frac{B_{0} R T-2 A_{0}-\frac{4 C_{0}}{T^{2}}}{v_{m}}+\frac{2 b R T-3 a}{2 v_{m}^{2}}+\frac{6 \alpha a}{5 v_{m}^{5}}+\frac{c}{T^{2} v_{m}^{2}} \cdot\left[3 \cdot \frac{1-e^{\frac{-\gamma}{v_{m}^{2}}}}{\gamma} \cdot v_{m}^{2}+\left(\frac{\gamma}{v_{m}^{2}}-\frac{1}{2}\right) \cdot e^{\frac{-\gamma}{v_{m}^{2}}}\right]$

$S_{m}=s_{m}^{0}+R \ln \frac{v_{m}}{R T}-\frac{B_{0} R+\frac{2 C_{0}}{T^{3}}}{v_{m}}-\frac{R b}{2 v_{m}^{2}}+\frac{2 c}{T^{3} v_{m}^{2}} \cdot\left(\frac{1-e^{\frac{-\gamma}{v_{m}^{2}}}}{\gamma} \cdot v_{m}^{2}-\frac{1}{2} \cdot e^{\frac{-\gamma}{v_{m}^{2}}}\right)$

$c_{v m}=c_{v m}^{0}+\frac{6 C_{0}}{T^{3} v_{m}}-\frac{3 c}{T^{3} v_{m}^{2}} \cdot\left(2 \cdot \frac{1-e^{\frac{-\gamma}{v_{m}^{2}}}}{\gamma} \cdot v_{m}^{2}-e^{\frac{-\gamma}{v_{m}^{2}}}\right)$

$c_{p m}=c_{v m}+R \cdot\left[1+\frac{B_{0}+\frac{2 C_{0}}{R T^{3}}}{v_{m}}+\frac{b}{v_{m}^{2}}-\frac{2 c}{R T^{3} v_{m}^{2}} \cdot\left(1+\frac{\gamma}{v_{m}^{2}}\right) \cdot e^{\frac{-\gamma}{v_{m}^{2}}}\right]^{2} \cdot Q$

$Q=\left[1+2 \cdot \frac{B_{0}-\frac{A_{0}}{R T}-\frac{C_{0}}{R T^{3}}}{v_{m}}+3 \cdot \frac{b-\frac{a}{R T}}{v_{m}^{2}}+\frac{6 \alpha a}{R T v_{m}^{5}}+\frac{c}{R T^{3} v_{m}^{2}} \cdot\left(3+\frac{3 \gamma}{v_{m}^{2}}-\frac{2 \gamma^{2}}{v_{m}^{4}}\right) \cdot e^{\frac{-\gamma}{v_{m}^{2}}}\right]^{-1}$

where:

$p$ - the pressure (MPa)

$u_{m}$ - the molar internal energy of gas $\left(\mathrm{kJ}^{\mathrm{kmol}}{ }^{-1}\right)$

$i_{m}$ - the molar enthalpy of gas $\left(\mathrm{kJ}^{\mathrm{kmol}}{ }^{-1}\right)$

$s_{m}$ - the molar entropy of gas $\left(\mathrm{kJ} \cdot \mathrm{kmol}^{-1} \cdot \mathrm{K}^{-1}\right)$

$c_{v m}$ - the molar specific heat capacity of a gas at a constant volume $\left(\mathrm{kJ} \mathrm{kmol}{ }^{-1} \cdot \mathrm{K}^{-1}\right)$

$C_{p m}$ - the molar specific heat capacity of a gas at a constant pressure $\left(\mathrm{kJ} \cdot \mathrm{kmol}^{-1} . \mathrm{K}^{-1}\right)$

$Q$ - the coefficient of BWR equation (-)

Table 5 Values of gases state quantities at their critical point $[3,4]$

\begin{tabular}{|c|c|c|c|c|}
\hline Gas & $\begin{array}{c}\text { Temperature } \\
\left({ }^{\circ} \mathbf{C}\right)\end{array}$ & $\begin{array}{c}\text { Pressure } \\
(\mathbf{M P a})\end{array}$ & $\begin{array}{c}\text { Density } \\
\left(\mathbf{k g}^{-\mathbf{3}} \mathbf{)}\right.\end{array}$ & $\begin{array}{c}\text { Specific volume } \\
\left(\mathbf{m}^{3} \cdot \mathbf{k m o l}^{-1} \mathbf{)}\right.\end{array}$ \\
\hline $\mathrm{CO}$ & -140.2 & 3.491167 & 301 & 0.093058306 \\
\hline $\mathrm{CO}_{2}$ & 31 & 7.351065 & 463.9 & 0.094869476 \\
\hline $\mathrm{H}_{2}$ & -239.9 & 1.294478 & 31 & 0.065030323 \\
\hline $\mathrm{N}_{2}$ & -147.1 & 3.393101 & 311 & 0.090075241 \\
\hline $\mathrm{CH}_{4}$ & -82.5 & 4.628739 & 162 & 0.099031049 \\
\hline $\mathrm{Ar}$ & -122.4 & 4.864098 & 531 & 0.075231638 \\
\hline
\end{tabular}


$A_{0}, B_{0}, C_{0}, a, b, c, \alpha, y$ are the constants of the BWR equation characteristic for a given gas. The value of the constants together with the scope of validity are shown in Table 6.

The condition of temperature range and maximum pressure is met in the case of blast furnace gas expansion and for the condition of maximum reduced density, which is the ratio of density under the monitored conditions and density at the critical point, follows from Table $\mathbf{5}$ and Table $\mathbf{8}$, that it is also met.

Table 6 BWR equation constants for individual blast furnace gas components [1,2]

\begin{tabular}{|c|c|c|c|c|c|c|}
\hline Constant & $\mathrm{CO}$ & $\mathrm{CO}_{2}$ & $\mathbf{H}_{2}$ & $\mathbf{N}_{2}$ & $\mathbf{C H}_{4}$ & $\mathrm{Ar}$ \\
\hline $\mathrm{A}_{\circ}$ & 1.03115 & 2.7634 & 0.155164 & 1.1925 & 1.855 & 0.823417 \\
\hline $\mathrm{B}_{\circ}$ & 0.04 & 0.045628 & $2.08463 \mathrm{E}-05$ & 0.0458 & 0.0426 & 0.02228259 \\
\hline $\mathrm{C}_{\circ}$ & 11,240 & 113,330 & 395.164 & $5,889.07$ & 22,570 & $13,141.25$ \\
\hline $\mathrm{a}$ & 0.03665 & 0.051689 & -0.0016321 & 0.0149 & 0.0494 & 0.0288358 \\
\hline $\mathrm{b}$ & 0.0026316 & 0.0030819 & 0.000338337 & 0.00198154 & 0.00338004 & 0.0215829 \\
\hline $\mathrm{c}$ & 1,040 & $7,067.2$ & 7.26997 & 548.064 & 2,545 & 798.2437 \\
\hline$a$ & 0.000135 & 0.00011271 & -0.000121488 & 0.000291545 & 0.000124359 & $3.5589 \mathrm{E}-05$ \\
\hline $\mathrm{V}$ & 0.006 & 0.00494 & 0.0035073 & 0.0075 & 0.006 & 0.002338271 \\
\hline
\end{tabular}

Table 7 Area of constants validity ( $t$ - temperature, max. $d_{r}$ - maximum reduced density, max. $p$ - maximum pressure) $[1,2]$

\begin{tabular}{|c|c|c|c|c|c|c|}
\hline & $\mathbf{C O}$ & $\mathbf{C O}_{2}$ & $\mathbf{H}_{\mathbf{2}}$ & $\mathbf{N}_{\mathbf{2}}$ & $\mathbf{C H}_{4}$ & $\mathbf{A r}$ \\
\hline $\mathrm{t}\left({ }^{\circ} \mathrm{C}\right)$ & -25 to 200 & 0 to 275 & -150 to 50 & -163 to 200 & -140 to 200 & -111 to 327 \\
\hline max. dr $(-)$ & 0.2 & 2.1 & & 1.25 & 1.8 & 2.25 \\
\hline max. $\mathrm{p}(\mathrm{MPa})$ & 10 & 70 & 14 & 85 & 40 & 80 \\
\hline
\end{tabular}

Using the BWR equation (area of constants validity is shown in Table 7), the values of state quantities of the blast furnace gas individual components under normal conditions were determined - see Table 8 . These are needed to convert volume flow to mass flow.

I verified the dependence of the thermodynamic quantities of the blast furnace gas on the pressure using the BWR equation for different temperatures in the monitored range. The following Table 9 can serve as an example.

Table 8 Values of gases state quantities under normal conditions [5]

\begin{tabular}{|c|c|c|c|c|}
\hline Gas & $\begin{array}{c}\text { Temperature } \\
\left({ }^{\circ} \mathrm{C}\right)\end{array}$ & $\begin{array}{c}\text { Pressure } \\
(\mathrm{Pa})\end{array}$ & $\begin{array}{l}\text { Density } \\
\left(\mathbf{k g}^{-3} \mathbf{m}^{-3}\right.\end{array}$ & $\begin{array}{c}\text { Specific volume } \\
\left(\mathrm{m}^{3} \cdot \mathrm{kmol}^{-1}\right)\end{array}$ \\
\hline $\mathrm{CO}$ & \multirow{6}{*}{0} & \multirow{6}{*}{101,325} & 1.250417971 & 22.40095 \\
\hline $\mathrm{CO}_{2}$ & & & 1.976425283 & 22.267449 \\
\hline $\mathrm{H}_{2}$ & & & 0.089971256 & 22.406489 \\
\hline $\mathrm{N}_{2}$ & & & 1.250444471 & 22.402754 \\
\hline $\mathrm{CH}_{4}$ & & & 0.717489672 & 22.359946 \\
\hline $\mathrm{Ar}$ & & & 1.784013627 & 22.392206 \\
\hline
\end{tabular}


Table 9 Dependence of specific heat capacity $c_{p}$ on pressure

\begin{tabular}{|c|c|c|}
\hline $\begin{array}{c}\text { Pressure } \\
(\mathbf{M P a})\end{array}$ & $\begin{array}{c}\mathbf{C}_{\mathbf{p}} \text { for } \mathbf{t}=\mathbf{0}^{\circ} \mathbf{C} \\
\left(\mathbf{k J . k g} \mathbf{K}^{-1} \mathbf{)}\right.\end{array}$ & $\begin{array}{c}\mathbf{C}_{\mathrm{p}} \text { for } \mathbf{t}=\mathbf{5 0} \mathbf{}^{\circ} \mathbf{C} \\
\left(\mathbf{k J . k g}^{-1} . \mathbf{K}^{-1}\right)\end{array}$ \\
\hline 0.10 & 0.999494 & 1.009306 \\
\hline 0.12 & 0.999593 & 1.009367 \\
\hline 0.14 & 0.999692 & 1.009428 \\
\hline 0.16 & 0.999792 & 1.009490 \\
\hline 0.18 & 0.999891 & 1.009551 \\
\hline 0.20 & 0.999990 & 1.009612 \\
\hline 0.22 & 1.000089 & 1.009673 \\
\hline 0.24 & 1.000188 & 1.009734 \\
\hline
\end{tabular}

\section{CONCLUSION}

Calculations and mathematical modeling have confirmed that the dependence of thermodynamic quantities on pressure is negligible and does not need to be considered for common practical calculations.

Further calculations can be used to accurately determine the course of blast furnace gas expansion in the individual stages of the expansion turbine [6] and then the power of the electric generator. This is decisive for determining the return on investment for the possible use of an expansion turbine [7].

\section{REFERENCES}

[1] DEJČ, M.E. Technická dynamika plynů. Překlad Josef Malický. 1. vyd. Praha: SNTL, 1967. 659 s.

[2] NOVÁK, J.P., MALIJEVSKÝ, A., ŠOBR, J., MATOUŠ, J. Plyny a plynné směsi: stavové chování plynů, termodynamické vlastnosti plynů. 1. vyd. Praha: Academia, 1972. $203 \mathrm{~s}$.

[3] POLESNÝ, Bohumil a kol. Termodynamická data pro výpočet tepelných a jaderných energetických zařizení. 1. vyd. Brno: VUT, 1990. 213 s. Učební texty vysokých škol. ISBN 80-214-0160-5.

[4] HAŠEK, P. Tabulky pro tepelnou techniku. 2. vyd. Ostrava: Vysoká škola báňská, 1980. 247 s.

[5] BÁLEK, Stanislav. Tepelně technické tabulky a diagramy: určeno pro posl. hutnické fak. 3. vyd. Ostrava: Vysoká škola báňská, 1988. $129 \mathrm{~s}$.

[6] MELECKÝ, J., ZIEGLER, J. Možnosti využití expanzních turbín v podmínkách vysokopecních závodů. In: IV. Mezinárodní vědecká konference Modelling of the Metallurgical Processes and Their Industrial Applications. Szczyrk, 1994, s. l/110.

[7] TÓTH, A., MUDRÁK, L. Velké procesní expanzní turbíny ABB-PBS. In: 9. Mezinárodní konference vysokopecařů. Sborník referátů. Třinec, 1994, 76 s. 